\title{
The Utilization of Acid as a Color Stabilizer in the Extraction of Anthocyanins from the Lakum (Cayratia trifolia L.) Peel
}

Aryo E. Peluru \& *Paulus H. Abram

Program Studi Pendidikan Kimia/FKIP - Universitas Tadulako, Palu - Indonesia 94119

Received 20 September 2021, Revised 12 October 2021, Accepted 16 November 2021

doi: $10.22487 /$ j24775185.2021.v10.i4.254-259

Abstract

Anthocyanins are a group of natural dyes (pigments) that give many colors to plants' leaves, flowers, and fruits. Anthocyanins are generally acidic and more stable under acidic conditions. One of the plants that contain anthocyanin is the lakum (Cayratia trifolia L.) fruit ripe with a blackish-purple color. This study aimed to determine the best type of acid used to extract anthocyanins from the lakum fruit peel. The extraction process was carried out by maceration method using $96 \%$ ethanol solvent acidified with three types of acids, $\mathrm{HCl} 1 \%$, citric acid 3\%, and acetic acid 3\%, with an average level of anthocyanin obtained of 283.88, 220.70, and $226.55 \mathrm{mg} / \mathrm{L}$, respectively. This study indicates that the best acid used to extract anthocyanin from the lakum fruit peel with the highest total anthocyanin results is by adding HCl $1 \%$.

Keywords: Lakum skin, anthocyanin, extraction, $\mathrm{HCl}$, citric acid, acetic acid

\section{Introduction}

Anthocyanins are compounds from the flavonoid group and are a group of natural dyes that are abundant in nature that give pink, dark red, purple, and blue colors to the leaves, flowers, and fruits of plants (Saati, 2016). Anthocyanins are found in vacuoles in plant cells in several different tissues such as leaves, petals, fruits, tubers, or stems (Silva et al., 2017). The basic structure of anthocyanins is derived from the flavylium cation, as shown in Figure 1.<smiles>[R]c1cc2c([R])c([R])c([R])cc2[o+]c1-c1cc([R])c([R])c([R])c1</smiles>

Figure 1. The basic structure of anthocyanins

One of the plants that contain anthocyanins is the lakum fruit (Cayratia trifolia L.). This can be seen from the characteristics of the lakum fruit, which has green fruit when it is still unripe and dark purple-black when it is fully ripe. The purple color on the ripe lakum fruit indicates the presence of pigment from the anthocyanin group. This pigment causes lakum fruit to be used as a natural dye (Panarigas \& Idiawati, 2015). Apriyani et al. (2016) have researched methanol extract of lakum fruit as an alternative to synthetic indicators, especially phenolphthalein (pp) indicators in the strong basestrong acid titration process. Some plants that contain lots of anthocyanins have been used as natural dyes in foodstuffs, such as grapes and strawberries. Natural dyes have long been used as a food coloring and are still safer than synthetic ones. In recent years, the use of natural dyes has become increasingly popular because it can reduce the use of synthetic dyes that are harmful to health and are not environmentally friendly (Ali et al., 2016).

Synthetic dyes have more advantages than natural dyes, which are more stable, more uniform, have a more substantial coloring power, and are usually cheaper (Yulianti, 2017). Natural dyes from vegetable and animal sources generally have lower color stability than synthetic dyes. In addition to being useful as natural dyes, anthocyanins also act as antioxidants that can fight free radicals that enter the body (Priska et al., 2018).

Anthocyanins are easily damaged when processing fruits and vegetables that contain these pigments. Several conditions that can affect the rate of anthocyanin breakdown are temperature, light, $\mathrm{pH}$, and oxygen (Mahdavi et al., 2016).

Isolation of anthocyanin pigments is done by extracting the material using a solvent that matches the polarity of the substance to be extracted. The function of the solvent for anthocyanin extract is a

${ }^{*}$ Correspondence:

Paulus H. Abram

e-mail: Paulusabram15@gmail.com

(c) 2021 the Author(s) retain the copyright of this article. This article is published under the terms of the Creative Commons Attribution-NonCommercial-ShareAlike 4.0 International, which permits unrestricted non-commercial use, distribution, and reproduction in any medium, provided the original work is properly cited. 
factor that determines the quality of extraction and has excellent dissolving power. The extraction of anthocyanins needs to pay attention to several factors. The choice of extraction method depends on the nature of the material and the compound to be isolated (Ningsi, 2018).

Anthocyanin pigments are polar compounds and can be extracted with polar solvents. Some polar solvents include ethanol, water, and ethyl acetate. The selection of water as a solvent in anthocyanin extraction showed poor results for extracting anthocyanins. This is because water is not a solvent often used for extraction, and spoilage is easy because water is an accessible medium for bacteria to grow. According to Afandy et al. (2017), anthocyanins can be extracted with various types of solvents, but the most effective is using methanol acidified with $\mathrm{HCl}$. However, due to the toxic nature of methanol, usually, in the food system, water or ethanol acidified with $\mathrm{HCl}$ is used.

It is recommended that anthocyanin pigment extraction be carried out in an acidic environment because the acid serves to optimize the extraction of anthocyanins further so that the anthocyanin pigments do not change color quickly and can denature plant cell membranes, then dissolve the anthocyanin pigments so that they can leave the cells, and prevent oxidation. Generally, extracting anthocyanins uses solvents and acids because anthocyanin pigments are more stable when extracted using water or acidified alcohol as solvents. Extraction of anthocyanins in an acid state further increased the yield's effectiveness and the obtained anthocyanin value. Anthocyanins are generally acidic and more stable under acidic conditions (Achyadi, 2019).

The addition of acid to the extraction of anthocyanins is very influential; it can be seen from the research conducted by Adam (2015) regarding the analysis of total anthocyanins from red spinach leaves based on the effect of adding the type of acid, where the results obtained were the entire anthocyanin content of the extract with ethanol solvent added with $1 \mathrm{M} \mathrm{HCl}$, acid 3\% citrate, $25 \%$ $\mathrm{CH}_{3} \mathrm{COOH}$ and no acid, respectively, 132.76, $121.56,107.21$, and $76.98 \mathrm{mg} / \mathrm{L}$.

Based on the description above, this paper aims to present the determination of acid type most effectively used to extract anthocyanins from the skin of lakum fruit, seen from the anthocyanin levels obtained from each addition of acid. It is hoped that this research can provide information regarding the best type of acid added to the anthocyanin extraction of the lakum fruit peel.

\section{Methods}

The tools used in this research are beaker, measuring flask, dropper, stir bar, spatula, Erlenmeyer, blender, knife, dark bottle, analytical balance, centrifuge, Buchner funnel, vacuum rotary evaporator, and UV-Vis spectrophotometer.

The material used is the skin of the lakum fruit obtained from the Palu city area, 96\% ethanol, 1\%
$\mathrm{HCl}, 3 \%$ acetic acid, $3 \%$ citric acid, $\mathrm{pH} 1$ buffer solution, and $\mathrm{pH} 4.5$ buffer.

\section{Sample preparation}

Samples of ripe fresh lakum fruit were washed in running water to remove dirt on the fruit's skin, then separated the flesh and skin of the fruit. After that, the skin of the lakum fruit, separated from the fruit's flesh, is blended until smooth to reduce the size of the skin of the lakum fruit, thus facilitating the extraction process.

\section{Preparation of buffer solution $\mathrm{pH} 1.0$ and 4.5}

The concentration of anthocyanin compounds in this method is $\mathrm{pH} 1.0$ and 4.5. The reason for choosing this $\mathrm{pH}$ is because at $\mathrm{pH} 1.0$, anthocyanins form colored oxonium compounds (flavilium cations) at $\mathrm{pH}$ 4.5; they form colorless carbinol/hemiketals.

\section{Buffer solution $p H 1.0$}

A total of $0.465 \mathrm{gram} \mathrm{KCl}$ was dissolved with distilled water in a $250 \mathrm{ml}$ volumetric tube to the limit. Then add $\mathrm{HCl}$ until the $\mathrm{pH}$ reaches $1.0 \pm 0.1$.

\section{Buffer solution pH 4.5}

A total of 8.2 grams of sodium acetate was dissolved with distilled water in a $250 \mathrm{ml}$ volumetric tube to the limit. Add the $\mathrm{HCl}$ solution until the $\mathrm{pH}$ is $4.5 \pm 0.1$.

\section{Sample extraction}

Extraction of lakum fruit peel in this study was carried out using the maceration extraction method. According to the anthocyanin solubility properties, maceration attracts anthocyanin compounds using a solvent. The use of the maceration method considers the solubility properties of the material (sample) to be extracted and is very advantageous in isolating compounds from natural materials; besides, this method is straightforward. Other procedures such as soxhlet are not carried out in this extraction process because of anthocyanins' nature, easily degraded by heat because flavonoid compounds are easily oxidized at high temperatures.

Extraction begins by weighing the skin of the lakum fruit blended and put into three closed containers of 100 grams each; extraction is carried out by maceration with the proportion of ingredients and solvents being 1:4 at room temperature for 24 hours.

The type of solvent used is $96 \%$ ethanol, each of which is acidified with $1 \% \mathrm{HCl}$, sitrat $3 \%$; extraction begins by weighing the skin of the lakum fruit that has been blended and put into three closed containers of 100 grams each, extraction is carried out by maceration with the proportion of ingredients and solvents being 1:4 at room temperature for 24 hours. The solvent used is $96 \%$ ethanol, acidified with $1 \% \mathrm{HCl}$.

\section{Determination of total anthocyanin level}

Determination of total anthocyanins was carried out using the differential $\mathrm{pH}$ method (Vega 
et al., 2017), namely by measuring the absorbance of the lakum fruit extract at $\mathrm{pH} 1$ and $\mathrm{pH} 4.5$ measured at wavelengths of $510 \mathrm{~nm}$ and $700 \mathrm{~nm}$. In this study, the instrument used to measure the transmittance or absorbance of the sample is a UVVis spectrophotometer. UV and visible (UV-Vis) spectroscopy analysis is the single most helpful way to analyze the structure of flavonoids. This is because the characteristics of the same spectrum provide data about the same type of compound. The advantage of this spectroscopy method is that very few samples are required for analysis.

The following formula determines the absorbance value of the sample:

$$
A=\left\{\left(A_{510}-A_{700}\right) p H 1-\left(A_{510}-A_{700)} p H 4,5\right\}\right.
$$

The anthocyanin content of the sample is calculated by the formula: Total anthocyanin

$$
(\mathrm{mg} / \mathrm{L})=\frac{A \times M W \times D F \times 1000}{\epsilon \times b}
$$

where A is absorbance; $\mathrm{MW}$ is the molecular weight of cyanidine-3-glucoside $(449.2 \mathrm{~g} / \mathrm{mol})$; DF is the dilution factor; is the Absorption of cyanidin-3glucoside $(26,900 \mathrm{~L} / \mathrm{mol} \mathrm{cm})$; $b$ is the width of the cuvette (Hosseini et al., 2016).

\section{Results and Discussion}

Based on the calculation results and measurement of absorbance with three repetitions, data on anthocyanin levels in the skin of the lakum fruit can be seen in Tables 1-3.

\begin{tabular}{|c|c|c|c|c|c|}
\hline \multirow{3}{*}{ Repetition } & \multicolumn{4}{|c|}{ Absorbance } & \multirow{3}{*}{ Total Anthocyanin $(\mathrm{mg} / \mathrm{L})$} \\
\hline & \multicolumn{2}{|c|}{ pH 1} & \multicolumn{2}{|c|}{$\mathrm{pH} 4.5$} & \\
\hline & $\lambda 510 \mathrm{~nm}$ & $\lambda 700 \mathrm{~nm}$ & $\lambda 510 \mathrm{~nm}$ & $\lambda 700 \mathrm{~nm}$ & \\
\hline 1 & 1075 & 0.033 & 0.372 & 0.015 & 285.97 \\
\hline 2 & 1078 & 0.033 & 0.369 & 0.004 & 283.88 \\
\hline 3 & 1079 & 0.038 & 0.369 & 0.038 & 281.79 \\
\hline \multicolumn{5}{|c|}{ Average } & 283.88 \\
\hline
\end{tabular}

Table 1. Total anthocyanins of lakum fruit extract with the addition of $\mathrm{HCl}$

Table 2. Total anthocyanins of lakum fruit peel extract with the addition of citric acid

\begin{tabular}{cccccc}
\hline \multirow{5}{*}{ repetition } & \multicolumn{3}{c}{ Absorbance } & Total Anthocyanin (mg/L) \\
\cline { 3 - 6 } & $\lambda 510 \mathrm{~nm}$ & $\lambda 700 \mathrm{~nm}$ & $\lambda 510 \mathrm{~nm}$ & $\lambda 700 \mathrm{~nm}$ & \\
\cline { 3 - 6 } 1 & 0.762 & 0.027 & 0.23 & 0.029 & 222.93 \\
2 & 0.766 & 0.019 & 0.232 & 0.028 & 226.69 \\
3 & 0.764 & 0.03 & 0.235 & 0.015 & 212.68 \\
\hline \multicolumn{7}{c}{ Average } \\
\hline
\end{tabular}

Table3. Total anthocyanins of lakum fruit peel extract with the addition of acetic acid

\begin{tabular}{cccccc}
\hline \multirow{5}{*}{ repetition } & \multicolumn{2}{c}{ Absorbansi } & Total Anthocyamin (mg/L) \\
\cline { 3 - 6 } & $\lambda 510 \mathrm{~nm}$ & $\lambda 700 \mathrm{~nm}$ & $\lambda 510 \mathrm{~nm}$ & $\lambda 700 \mathrm{~nm}$ & \\
\hline 1 & 0.785 & 0.024 & 0.234 & 0.015 & 226.27 \\
2 & 0.785 & 0.027 & 0.24 & 0.013 & 221.68 \\
3 & 0.788 & 0.015 & 0.236 & 0.018 & 231.69 \\
\hline \multicolumn{7}{c}{ Average } \\
\hline
\end{tabular}

\section{Anthocyanin levels}

Anthocyanins are phenolic compounds and provide natural color in fruits, flowers, leaves, and vegetables. And is divided into three main parts, namely anthocyanidins, aglycones, and glucosides.
In addition, anthocyanin compounds belong to the flavonoid group, which function as antioxidants(Anggraeni et al., 2018). Anthocyanins are soluble in polar solvents such as methanol, acetone, or chloroform water, acidified with hydrochloric acid or formic acid. 
Anthocyanin pigments are generally acidic and more stable under acidic conditions. The more acidic conditions. Significantly closer to $\mathrm{pH} 1$. will cause more anthocyanin pigments to be in the form of colored flavilium or oxonium cations. The absorbance measurement will show an increasing number of anthocyanins.

\section{Anthocyanin levels with the addition of $\mathrm{HCl}$}

After being analyzed and calculated, the average anthocyanin content of lakum fruit peel with 96\% ethanol solvent added with $1 \%$ hydrochloric acid $(\mathrm{HCl})$ is $283.88 \mathrm{mg} / \mathrm{L}$. The results obtained can be seen in Table 1 . These results show the highest anthocyanin levels obtained. Compared with 3\% acetic acid and 3\% citric acid. This is in line with research conducted by Adam (2015) regarding the analysis of total anthocyanins from spinach leaves red based on the effect of the addition of acid. The highest anthocyanin content was found in samples with ethanol solvent added with $1 \% \mathrm{HCl}$ with anthocyanin levels obtained that was $132.76 \mathrm{mg} / \mathrm{L}$. And research conducted by Anggraeni et al. (2018) regarding determining total anthocyanin levels of brown rice where $1 \% \mathrm{HCl}$ in the extraction resulted in the highest anthocyanin levels. But in this study, the solvent used was methanol, and the results obtained were refined rice samples dissolved with $1 \%$ methanol $\mathrm{HCl}$, which had the highest anthocyanin content.

Anthocyanin extraction can be carried out with several solvents such as water, ethanol, methanol. But the most effective is by using methanol acidified with $\mathrm{HCl}$. However. Due to the toxic nature of methanol usually in the food system. Water or ethanol acidified with $\mathrm{HCl}$ is used. Still, according to Anggraeni et al. (2018), the selection of water as a solvent in the extraction of anthocyanins in brown rice shows that the extraction results are not suitable for extracting anthocyanins in brown rice. This is because water is not a solvent that is often used for extraction, and it is easy for spoilage to occur. Because water is a medium that is easy for bacteria to grow.

According to Faridah (2016), the difference in the total anthocyanin produced for each addition of a type of acid is related to the difference in the dissociation constant of each acid. $\mathrm{HCl}$ has a higher dissociation constant than acetic acid and citric acid. The dissociation constant for $\mathrm{HCl}$ is $10^{7}$. The acetic acid has a dissociation constant of $1.75 \times 10-5$ and citric acid $7.21 \times 10^{-4}$. The greater the dissociation constant. The stronger the acid, the greater the number of hydrogen ions released into the solution. An increasingly acidic situation will cause more anthocyanin pigments to be in the form of colored flavilium cations. This is due to the denaturation of plant cell membranes, which then dissolve anthocyanin pigments and leave the cells to increase the absorbance measurement.
Anthocyanin levels with the addition of citric acid

After being analyzed and calculated, the average anthocyanin content of lakum fruit peel with $96 \%$ ethanol solvent added with 3\% citric acid is $220.70 \mathrm{mg} / \mathrm{L}$. The results obtained can be seen in Table 2. These results indicate the lowest anthocyanin levels obtained. This is also in line with Tazar et al. (2018) research where anthocyanin extraction using distilled water as a solvent added with $1 \%$ citric acid is the best treatment in extracting anthocyanins from senduduk fruit with an anthocyanin concentration of $13.22 \mathrm{mg} / \mathrm{L}$.

In contrast to the research conducted by Kristiana et al. (2012), who said that 3\% citric acid and $1 \% \mathrm{HCl}$ affected the value of the total anthocyanin content of the anthocyanin pigment extract of the senggani fruit. Where the results of the study showed that extraction with $80 \%$ ethanol solvent with $3 \%$ citric acid added was able to produce a total anthocyanin content value greater than $1 \% \mathrm{HCl}$. This is because acidification with weak acids avoids hydrolysis of anthocyanins compared to strong acids such as $\mathrm{HCl}$. Citric acid is a weak organic acid that has a dissociation strength of $7.21 \times 10^{-4}$ nitric acid

This solution will form an equilibrium where the hydrogen ions are not entirely dissociated. So the acidity is higher stable. In addition, the more acidic solution will also cause hydrolysis of the glycosidic bonds of anthocyanins, resulting in less stable anthocyanins so that the anthocyanin compounds are damaged. This situation makes the anthocyanin extract more extracted in solvents acidified with citric acid.

\section{Anthocyanin levels with the addition of acetic acid}

After being analyzed and calculated, the average anthocyanin content of lakum fruit peel with $96 \%$ ethanol solvent added with 3\% acetic acid is $226.55 \mathrm{mg} / \mathrm{L}$. The results obtained can be seen in Table 3. These results indicate the second-highest anthocyanin content obtained after $1 \% \mathrm{HCl}$ compared to $3 \%$ citric acid. This is in line with Alvionita et al. (2016) research regarding the extraction and identification of anthocyanins from plantain buds. Where plantain buds with ethanol extract acidified with acetic acid obtained the highest levels of anthocyanins than those acidified with citric acid, which was $30.22 \mathrm{mg} / \mathrm{L}$.

According to Alvionita et al. (2016), when compared in terms of acid, the anthocyanin content of extracts with acetic acid is higher than that of citric acid. The pKa of acetic acid (4.76) is smaller than the pKa of citric acid (6.39). So that acetic acid is much stronger in acidity, which causes the anthocyanin extract produced to be better in extracting. Basto's (2011) research on extracting anthocyanin pigments from mangosteen peel using $95 \%$ ethanol and acetic acid. the total anthocyanins were tiny. namely $0.8 \mathrm{mg} / 100 \mathrm{gram}$. compared to the addition of citric acid with a total anthocyanin of $0.10 \mathrm{mg} / 100 \mathrm{gram}$. This may be due to the ethanol and acetic acid solvents not having the same level of 
polarity as the anthocyanin pigments in the sample. However, in this study, the use of $96 \%$ ethanol acidified with 3\% acetic acid produced a higher total anthocyanin than the addition of $3 \%$ citric acid. The ethanol solvent acidified with acetic acid had the same relative polarity as the skin anthocyanin pigment. lakum fruit.

\section{Conclusions}

The more effective acid used in the extraction of anthocyanins in the skin of the lakum fruit is extraction using $96 \%$ ethanol solvent added with $1 \% \mathrm{HCl}$ because it gives the highest total anthocyanin yield $283.88 \mathrm{mg} / \mathrm{L}$. It compared to the addition of $3 \%$ citric acid and citric acid. 3\% acetate with anthocyanin levels obtained respectively $220.70 \mathrm{mg} / \mathrm{L}$ and $226.55 \mathrm{mg} / \mathrm{L}$.

\section{Acknowledgment}

The authors would like to thank the head of the Chemistry Education laboratory at Tadulako University. The head of the Mathematics and Natural Sciences laboratory at Tadulako University and all parties involved have helped this research to run well.

\section{References}

Achyadi, N. S. (2019). Pengaruh bahan pengekstrak terhadap karakteristik ekstrak senyawa fungsional dari kulit buah naga merah (hylocereus polyrhizus). Pasundan Food Technology Journal (PFTJ), 6(1), 23-30.

Adam, D. H. (2015). Analisis total antosianin dari daun bayam merah (Alternanthera amoena voss.) berdasarkan pengaruh penambahan jenis asam. Edu Science, 2(2), 9-12.

Afandy, M. A., Nuryanti, S., \& Diah, A. W. M. (2017). Ekstraksi ubi jalar ungu (Ipomoea batatas 1.) menggunakan variasi pelarut serta pemanfaatannya sebagai indikator asam-basa. Jurnal Akademika Kimia, 6(2), 79-85.

Ali, O. H., Al sayed, H., Yasin, N., \& Afifi, E. (2016). Effect of different extraction methods on stablity of anthocyanins extracted from red onion peels (allium cepa) and its uses as food colorants. Bulletin of the National Nutrition Institute of the Arab Republic of Egypt, 47(2), 124.

Alvionita, J., Darwis, D., \& Efdi, M. (2016). Ekstraksi dan identifikasi senyawa antosianin dari jantung pisang raja (musa x paradisica 1.) serta uji aktivitas antioksidannya. Jurnal Riset Kimia, 9(2), 21-28.

Anggraeni, V. J., Ramdanawati, L., \& Ayuantika, W. (2018). Penetapan kadar antosianin total beras merah (oryza nivara). Jurnal Kartika Kimia, 1(1), 11-16.

Apriyani, F., Idiawati, N., \& Destiarti, L. (2016). Ekstrak metanol buah lakum trifolia (cayratia trifolia (L.) domin) sebagai indikator alami pada titrasi basa kuat asam kuat. (JKK) Jurnal Kimia Khatulistiwa, 5(4), 74-78.
Basito. (2011). Efektivitas penambahan etanol 95\% dengan variasi asam dalam proses ekstraksi pigmen antosianin kulit manggis (garcinia mangostana 1.). Jurnal Teknologi Hasil Pertanian, 4(2), 84-93.

Faridah, A. (2016). Pengaruh umur simpan buah naga dan jenis pelarut terhadap ekstraks betasianin dari kulit buah naga merah (hylocereus polyrhizus). Jurnal Teknologi Pangan, 11(2), 1-11.

Hosseini, S., Gharachorloo, M., Ghiassi-Tarzi, B., \& Ghavami, M. (2016). Evaluation of the organic acids ability for extraction of anthocyanins and phenolic compounds from different sources and their degradation kinetics during cold storage. Polish Journal of Food and Nutrition Sciences, 66(4), 261-269.

Kristiana, H. D., Ariviani, S., \& Khasanah, L. U. (2012). Ekstraksi pigmen antosianin buah senggani (melastoma malabathricum auct. non linn) dengan variasi jenis pelarut. Jurnal Teknosains Pangan, 1(1), 105-109.

Mahdavi, S. A., Jafari, S. M., Assadpour, E., \& Ghorbani, M. (2016). Storage stability of encapsulated barberry's anthocyanin and its application in jelly formulation. Journal of Food Engineering, 181(July), 59-66.

Ningsi, A. L. (2018). Aktivitas antioksidan ekstrak daun tembakau (nicotiana tabacum l.) yang berasal dari desa cabbenge kabupaten soppeng. Unpublish Undergraduate Thesis. Makasar: Universitas Islam Negeri Alauddin Makassar.

Panarigas, H. D., \& Idiawati, N. (2015). Stabilitas ekstrak pigmen dari buah lakum (cayratia trifolia (l) domin) dan aplikasinya sebagai pewarna pangan. JKK (Jurnal Kimia Khatulistiwa), 4(3), 1-8.

Priska, M., Peni, N., Carvallo, L., \& Ngapa, Y. D. (2018). Antosianin dan pemanfaatannya. Cakra Kimia Indonesia, 6(2), 79-97.

Saati, E. A. (2016). Antioxidant power of rose anthocyanin pigment. ARPN Journal of Engineering and Applied Sciences, 11(17), 10201-10204.

Silva, S., Costa, E. M., Calhau, C., Morais, R. M., \& Pintado, M. E. (2017). Anthocyanin extraction from plant tissues: A review. Critical Reviews in Food Science and Nutrition, 57(14), 3072-3083.

Tazar, N., Violalita, F., \& Harni, M. (2018). Pengaruh metoda ekstraksi terhadap karakteristik ekstrak pekat pigmen antosianin dari buah senduduk (melastoma malabathricum 1.) serta kajian aktivitas antioksidannya. Lumbung, 17(1), 10-17.

Vega-Arroy, J. D., Ruiz-Espinosa, H., LunaGuevara, J. J., Luna-Guevara, M. L., Hernandez-Carranza, P., Avila-Sosa, R., \& Ochoa-Velasco, C. E. (2017). Effect of solvents and extraction methods on total anthocyanins, 
phenolic compounds and antioxidant capacity of renealmia alpinia (rottb.) maas peel. Czech Journal of Food Sciences, 35(5), 456-465.
Yulianti, I. (2017). Tanggung jawab sosial terhadap pemakaian pewarna sintetik rhodamin $b$ pada masyarakat. Jurnal TEDC, 11(3), 229-235. 